\title{
Comparison of Grower Advisory Systems in Europe
}

\author{
Richard C. Funt ${ }^{1}$ \\ Department of Horticulture, 2001 Fyffe Road, The Ohio State University, Columbus, OH 43210
}

\author{
Julian A.H. Nicholson ${ }^{2}$ \\ Farm Business Unit, Wye College, University of London, Wye, Ashford, Kent, U.K.
}

Funding for extension in the United States has declined in real dollars and, therefore, the number of persons employed has declined. During the 1980s, the federal budget remained rather constant and some states tried to increase their budgets to maintain programs. Growers generally have been reluctant to pay for education programs. However, many states charge registration fees, in addition to charging for bulletins and newsletters. Many people are questioning these charges at a time when new technologies (computers, voice mail, etc.) are emerging.

While R.C.F. was on professional leave at the Farm Business Unit, Wye College, Kent, England, in 1985, we found a need to compare extension (advisory) systems in Europe. Why? First, governments were reducing support for extension. In 1985, England was drastically cutting research and extension funding and proposing to eliminate research stations (and they have!). Second, from a traditional U.S. extension viewpoint, I (R. C. F.) wondered how anyone could survive in private advising. Yet, England has always had a strong private advising (consultant) group, particularly in horticulture (Bristow, 1983). Furthermore, under government cuts, only a few extension workers would survive in public advising in England. Our objective was to compare public and private advisory systems and to define the components of success.

To carry out this project, we first had to realize that Europe has high agricultural production and therefore faces a food surplus. Europeans have also reduced the number of public extension workers by $50 \%$ in some areas. The number of growers has declined to $<5 \%$ of the total population in several European countries. Indeed, we in the United

Received for publication 10 Nov. 1989. We are grateful to those persons who contributed to this survey. The cost of publishing this paper was defrayed in part by the payment of page charges. Under postal regulations, this paper therefore must be hereby marked advertisement solely to indicate this fact.

${ }^{1}$ Professor, Extension Horticulturist.

${ }^{2}$ Lecturer; Past Chairman, Intl. Soc. Hort. Sci. Labor and Management Group.
States face problems in 1991 similar to those that Europeans faced 5 to 15 years ago.

In the early 1980s, Europe was producing surplus grain and milk, exporting wine and juice concentrates to the United States, and producing food at a cost equal to that of the United States (Table 1). The efficient horticultural production and marketing systems developed in Holland are especially outstanding. This surplus was created with fewer extension personnel and fewer farmers than before World War II (Lipsey and Moore, 1985). The Common Agricultural Policy created the incentive for surplus grain production by supporting the price for wheat at $45 \%$ above the average world price (Burrell et al., 1984). Therefore, total government agricultural funding (including price supports) has increased in recent years, but government funding for extension has decreased. Thus, governments that once provided growers with information, loans, and price support appear to reduce funding during economic certainty (peace, food surplus, high production, etc.) and tend to support agricultural information and other agricultural-related programs at higher levels during economic uncertainty (war, famine, flood, etc.)

\section{Advisory service interview}

On-site interviews of five advisory services in horticulture advisory systems were conducted. Four of these were in European Economic Community (EEC) countries and the fifth in Sweden, a country with horticulture somewhat similar to the United Kingdom. The services were chosen on the basis of their diversity, perceived success, and having operated for more than 10 years. Advisors were questioned about their internal and external funding, how they approached growers, how they operated, and what they planned to do in the future.

\section{Sweden}

The Tradgardsekonomiska Undersokningen (TEU) is a private advisory service housed on the Swedish Univ. of Agricultural Science campus at Alnarp. The TEU staff consists of three full-time and five part-time employees, including an economist, two horticulturists, a computer programmer, and a secretary. They provide biological, economical, and technological information to more than 80 growers.

The main objective of TEU is to improve product quality, planning, crop combinations, and long-range investment (J. Ottosson, 1982). A TEU employee interviews a client at the latter's request and then writes a report. The grower then decides for what information he will pay. TEU personnel make three farm visits per year and follow each stage of crop development. These advisors monitor the growth and yield of tomatoes or cucumbers; hence, they anticipate problems, a better approach than that of advisors first arriving during mid-crop production. TEU establishes a group meeting of eight to 12 growers to compare each manager's performance within 3 to 6 weeks after final harvest. TEU advisors ask questions at these meetings and growers make the decisions. TEU does not have local research stations, but does have trials in nurseries.

Based on the comparisons made in this study, TEU appears to be one of the world's finest and most effective private advisory services. Freedom from "red tape" and from conflict with a public system allows TEU to approach its job with innovation, enthusiasm, and satisfaction derived from very close contact with its clientele; it provides a complete approach to advising, i.e., biological, economical, and technological. TEU personnel work with grower groups that foster a basic human need to belong-motivating, encouraging, and acting as a catalyst rather than dictating action. Grower response is highly favorable, and growers are very willing to pay $\$ 50 / \mathrm{h}$ for advice. Their system is simple but effective.

\section{England}

The Agricultural Development and Advisory Service (ADAS) is a public advisory service in England that has gone through major personnel cuts in 1971 and 1985-88. ADAS administers the government's agricultural policy and is not associated with any university. Its members belong to a union that bargains for salary increases. In 1984, ADAS spent $£ 122.7$ million $(£ 1=$ U.S. $\$ 1.57,29$ Nov. 1989), of which $30 \%$ was 
Table 1. General statistics of countries used in European study, 1985.

\begin{tabular}{|c|c|c|c|c|c|c|}
\hline \multirow[b]{2}{*}{ It e m } & \multicolumn{6}{|c|}{ Country $^{2}$} \\
\hline & Sweden & $\begin{array}{l}\text { United } \\
\text { Kingdom }^{y}\end{array}$ & Netherlands & Italy & $\begin{array}{c}\text { West } \\
\text { Germany }\end{array}$ & $\begin{array}{c}\text { United } \\
\text { States }\end{array}$ \\
\hline $\begin{array}{l}\text { Total population } \\
\text { (millions) }\end{array}$ & 8 & 56 & 14 & "57 & 62 & 239 \\
\hline $\begin{array}{l}\text { No. of farms } \\
\text { (thousands) }\end{array}$ & 132 & 24.4 & 4.0 & 2193, & 764 & 2400 \\
\hline $\begin{array}{l}\text { No. of hectarage } \\
\text { (millions) }\end{array}$ & 1.3 & 18.4 & 2.1 & 17.6 & 13.1 & 451.5 \\
\hline $\begin{array}{l}\text { Average hectare/farm } \\
\text { Amount spent }\end{array}$ & 9.9 & 74.7 & 17 & 8.0 & 12.3 & 188.3 \\
\hline for food $(\%)$ & 20 & 18 & 15 & 26 & 14 & 15 \\
\hline
\end{tabular}

${ }^{2}$ U.S. Dept. of Agriculture (1983).

${ }^{y}$ Figures are approximate and data are from 1980 to 1984.

for advice, $37 \%$ for regulatory allocations, and $32 \%$ for research and development (Ministry of Agriculture, 1984). The 1983 value of all agriculture output was $£ 10,600$ million, which contributed $2.1 \%$ of the gross domestic product (Bell, 1984). The government decided to cut all funding by $£ 23$ million in 1985-86 (Bell, 1985).

While public funding was being cut, ADAS increased expenditures for computers. (R.L. Bell, ADAS director, is very supportive of computerization,) An automatic invoicing system will increase in-house and in-field efficiency after an information database is built. However, a substantial training investment will be necessary. ADAS is considering a charge of $£ 150$ to $£ 200$ per farm to generate $£ 15$ million. Further, private advising is strong and has established itself in the most productive areas. Thus, ADAS and private advisors will compete for fewer and fewer farmers in the future, which, in the long run, is an advantage to farmers who are willing to pay for advice (Volan, 1985). It will be interesting to follow the success of a publicfunded advisory service that operates with a private-business approach.

The Farm Advisory Services Team (FAST) in England is a private advisory service to 120 growers who own 7800 ha of fruit, grain, and hops. It is managed by a former public advisor and is guided by a nine-member advisory board. Nearly $90 \%$ of the growers are within $32 \mathrm{~km}$ of the office, which consists of nine advisors, six full-time secretaries, and three laboratory and two training personnel.

FAST provides a comprehensive service in cultural practices and pest control and soil, leaf, and fruit analysis. It combines pesticide orders from growers to obtain lower prices through volume discounts. Fees are established at a basic fee below 20 ha, and a sliding scale is placed on a hectare basis for additional land. Additional charges are applied for biweekly pest monitoring from April to September. Weekly newsletters, annual reports, and annual grower meetings are available to growers. FAST also has its own land for research'. It wants every farm to have a computer for receiving electronic mail. Computerized automatic weather recording is being tested.

\section{Netherlands}

The Dutch have built a financially strong industry around small family farms. About
$80 \%$ of Holland's agricultural products are exported to northern Germany, other EEC countries, and the United States through various marketing strategies supported by the central government.

Research stations, located within the concentrated production areas, are supported 50\% by the government and $50 \%$ by growers. Fruit growers pay by the number of hectares of planted fruit, while glasshouse growers pay a modest percentage of auction turnover. Growers also pay a small membership fee to the research station to receive its publications. The Dutch demonstrate a strong belief in themselves and therefore believe that they must invest in research to aid in provision of jobs and exports, to increase revenues, and enhance returns to the grower. The Dutch advisory service is state-funded, even though some personnel are based at research stations.

\section{Italy}

In 1957, growers in Bozen Province formed the Southern Tyrolean Advisory Service for Fruit and Wine Growing. Four thousand members control two-thirds of the production area and meet annually to elect a managing board and chairman. They export $60 \%$ to $80 \%$ of their fruit, with $55 \%$ going to West Germany (Oberhofer, 1982).

In 1971, the provincial government enacted a law assuring a contribution of $75 \%$ of costs if the membership pays a $25 \%$ fee $\left(\$ 33.65 /\right.$ ha $^{-}$year $\left.^{-1}\right)$. Members receive bulletins and monthly magazines. Those who do not pay by February of a given year do not receive the publications. The advisory staff consists of 24 people: four with doctorates, three with bachelor degrees, and 11 technicians and six secretaries. This staff works with a local research station that is solely funded by the province and has a similar staff. During the winter, the advisors organize courses in pruning, planting systems, cultivars, and rootstock. At bud burst, conferences are given on fertilizer, spraying, and frost protection. In spring and summer, there are orchard walks by grower groups. They strive to inform members about national and international research stations and advisory services. The close relationship of the advisor to the grower group allows the advisor to seek additional funding for study tours, e.g., to Kent, U.K.

\section{Overview}

All of the public and private systems surveyed in Europe appear to be successful, even though funding for agricultural extension and research has declined significantly since 1970 under the climate of peace, food surplus, and governmental stability. The major emphasis has been placed on production agriculture and not the other components $(4-\mathrm{H}$, community and natural resources development, etc. ) that are a part of the U.S. extension service. Private advising in certain areas will meet the demand for information as advisors leave the public sector.

Europe is now an exporter of food, not an importer as they were before 1970, and will continue to compete with the United States to sell grain and milk to the Soviet Union and Eastern Europe, simply because they are efficient and closer to the market than the United States. Growers in Europe, because of their confidence in production and marketing, are more willing to pay for advice when the advice leads to greater net farm income, whether or not the information is provided by public or private sources. There are several ingredients for success in advisory services in these areas:

a) Information given has three elements: biological, economical, technological

b) There is a close working relationship with local research stations where practical information is developed

c) The information given is derived from local conditions that are closely related to the client's soil, weather, and crop development

d) Grower group participation is important both as an educational device and as a governing body. Confidence among growers and advisors is paramount

e) The information given is relevant to the market.

\section{Conclusion}

Funding for public advisory systems in Europe and the United States has declined over the past 10 years. The number of farmers has declined but production has increased. Surpluses of grain and milk were created and competition to sell these products increased. Technology and government support provided economic incentives to increase production.

Horticultural producers are willing to financially support public or private advising either in partial or full payment. In Sweden, growers pay the full rate, but the advisory group is housed on a university campus. In Italy, growers agree to pay a small portion of the cost, while the government pays the major portion. This agreement maintains a commitment from each group and provides strong interaction. Where public or private systems exist, high-quality, local, timely, and rapid delivery of information is vital for success. Continued success will depend on the adoption by advisory systems of electronic delivery of information via computers, biological and economical predictive modeling, and voice mail. 
Grower group participation is vital to any successful advisory program. The willingness to make a decision, to change, and to adopt new technology in a rapidly changing global economy is increased when the grower group has confidence in the advisory group. This confidence is greatly enhanced through periodic face-to-face group discussions.

These changes will challenge the traditional administration and staff in the U.S. land-grant system. Private sources of information can be selective as to clientele and work without bureaucratic functions. However, they must work longer to update their information. Greater leadership, flexibility, and judgment will be necessary in the landgrant system to meet the informational needs of growers who operate in a global economy.

\section{Literature Cited}

Bell, R.L. 1984. Report of a study of ADAS. MAFF, London. p. 1-20.

Bell, R.L. 1985. New challenges for ADAS. The Grower. 8 Aug. 1985. p. 3.

Bristow, C.M. 1983. Preliminary report on independent crop consulting in the United King dom. Dept. of Geology, Imperial College, Ascot, U.K. p. 1-10.

Burrell, A. M., N. W.F.B. Hill, and J.R. Med. land. 1984. Statistical handbook of UK Agriculture. Macmillan, London. p. 6-170.

Lipsey, D. and T. Moore. 1985. Cuts threat to farming subsidies. The Sunday Times. 18 Aug. 1985. p. 3 .
Ministry of Agriculture. 1984. At the farmer's service. Ministry of Agr., Fisheries, and Food Bklt. 2442. London. p. 5-74.

Oberhofer, H. 1982. Fruit growing in South Tyrol-History, present, outlook. S. Tyrolean Advisory Service. Bozen, Italy. p. 1-7.

Ottosson, J. (cd.). 1982. TEU 1964-1982. Swedish Univ. of Agr. Sci., Dept. Hort. Econ., Alnarp. p. 1:1-8, 21.

U.S. Department of Agriculture. 1983. Agricultural statistics. U.S. Dept. Agr. U.S. Government Printing Office, Washington, D.C.p. 710

Volan, K. 1985. Agricultural extension work in New Zealand. Edinburgh School of Agr., Econ. and Mgt. Dept., Edinburgh, Scotland. p. 1-62. 